\title{
Investigation of Various Events Occurring in the Brain Tissue After Calvarial Defects in Rats
}

\author{
Investigación de las Alteraciones Ocurridas en el Tejido Cerebral \\ Posterior a la Creación de Defectos en la Calvaria de Ratas
}

Mahmut Tas *; Ertugrul Gok**; Cenap Ekinci ${ }^{* * * *}$; Engin Deveci ${ }^{* * *}$ \& Senay Deveci*****

TAS, M.; GOK, E.; EKINCI, C.; DEVECI, E. \& DEVECI, S. Investigation of various events occurring in the brain tissue after calvarial defects in rats. Int. J. Morphol., 34(1):29-33, 2016.

SUMMARY: Bone damage and accidents, traumas can alter people's normal life, and damage the soft tissues. In this study, we aimed to investigate in calvarial defects in rats depending on the severity of cerebral contusion injury occurring in the temporal region. The rats were randomly divided into two groups: group 1 (control group), critical size cranial model with no treatment ( $\mathrm{n}=10$ ); group 2 (14-day synthetic graft group given $7^{\text {th }}$ day DEXA), critical size cranial model treated with Dexamethasone $(0.05 \mathrm{mg} / \mathrm{kg}$ intramuscular injection) +Synthetic graft $(\mathrm{n}=10)$ One calvarium defect of $7 \mathrm{~mm}$ was made in the parietal bone of each animal under general anesthesia. Calvarial defect results in dilatation of blood vessels, hemorrhage and deterioration was observed in glial fibrillary structures. Additionally, the increase in vascular endothelial growth factor expression showed a positive reaction with glial fibrillary acid protein astrocytes extensions. Apoptotic glial cells stained positive with Bcl-2. Calvarial defects caused by mild brain injury, to be induced by inflammatory cytokines, interrupting glial fibrillary degeneration by affecting the blood brain barrier is thought to promote apoptotic changes.

KEY WORDS: Calvarial defects; Rat; Cerebrum; Immunohistochemistry.

\section{INTRODUCTION}

Traumatic brain injury (TBI) is defined as damage to the brain resulting from an external mechanical force, such as that caused by rapid acceleration or deceleration, blast waves, crush, impact, or penetration by a projectile, and can lead to temporary or permanent impairment of cognitive, physical and psychosocial functions. Depending on the severity of injury, chronic constriction injury (CCI) results in an ipsilateral injury with cortical contusion, hemorrhage and blood-brain barrier disruption (Dhillon et al., 1994). Neuronal cell death and degeneration, astrogliosis, microglial activation, inflammatory events, axonal damage, cognitive deficits, excitotoxicity and cortical spreading depressions are reported to ensue (Uhl et al., 1994; Smith et al., 1995; Morales et al., 2005; Cernak, 2005; Griesbach et al., 2009). An increase of Glial Fibrillar Acidic Protein (GFAP) immunoreactivity is considered to be one sensitive marker of such injuries (Bignami, 1991).

Post traumatic brain edema is one of the pathophysiologic events occurring late as a secondary injury mechanism, and is thought to be generated in part by vasogenic edema due to blood brain barrier (BBB) breakdown and in part by cytotoxic edema (Koshinaga, 2000; Esen et al., 2003). Vascular Endothelial Growth Factor (VEGF) is a key player of angiogenesis in health and disease (Carmeliet, 2003). The creation of the calvarial defect is accomplished primarily by the use of a dental trephine with a dental drill against the superficial aspect of the calvarial. This exposure is achieved through midline incision and spreading of the skin, fascial and periosteal layers overlying the sagittal suture of the calvaria. The bone is not completely penetrated by the trephine to avoid damage to the underlying dural and brain tissues as the dura may play a role in bone healing and regeneration (Hobar et al., 1993, 1996). Instead the bone is thinned considerably and elevated using blunt instruments to separate the bone from the underlying dura. Dexamethasone (Dex) is also an inducing factor which stimulates the up-regulation of some major bone-related genes during osteogenesis. Bone has an architecture mainly composed of inorganic phase (70 \%) consisting of HA and

* Department of Emergency, Gazi Yasargil Training and Research Hospital, Diyarbakir, Turkey.

** The Council of Forensic Medicine of the Ministry of Justice, Diyarbakir Group Chairmanship, Diyarbakir, Turkey.

**** Department of Histology and Embryology, Faculty of Medicine, University of Dicle, Diyarbakir, Turkey.

***** Atatürk Health Services Vocational School, University of Dicle, Diyarbakir, Turkey. 
an organic fraction consisting of $95 \%$ Type I collagen (Fratzl et al., 2004).

Primary damage, which is seen immediately after trauma, and secondary damage, which is seen several hours or days later, occur after Traumatic brain injury (Gentile \& McIntosh, 1993). Two pathogenic mechanisms, excitotoxicity and apoptotic, have been described during the secondary damage. Using a model of combined traumatic brain injury and hypoxemia, Clark et al. (1997) observed an up-regulation of Bcl-2 in cortical and hippocampal neurons that survived the traumatic injury, Apoptosis may be induced by extracellular or intracellular events, such as oxidative stress or excess calcium (Kerr et al., 1972). In this study, we aimed to investigate in calvarial defects in rats of different depending on the severity of cerebral contusion injury occurring in the temporal region.

\section{MATERIAL AND METHOD}

The study protocol was approved by the Animal Research committee of Dicle University (DUHADEK), Turkey. Twenty (20) adult Sprague-Dawley rats, each weighing 180-220 g, were used as experimental animals. Animals were housed individually in plastic cages in a controlled environment $\left(21^{\circ} \mathrm{C} ; 12: 12\right.$ light cycle) and were given ad libitum access to drinking water and a diet of standard laboratory rat food pellets. The rats were randomly divided into two groups: group 1 (control group), critical size cranial model with no treatment ( $\mathrm{n}=$ 10); group 2 (14-day synthetic graft group given $7^{\text {th }}$ day DEXA), critical size cranial model treated with Dexamathasone $\quad(0.05 \quad \mathrm{mg} / \mathrm{kg} \quad$ intramuscular injection)+Synthetic graft. Animals were anesthetized with an intramuscular injection of ketamine hydrochloride (Ketavett, $5 \mathrm{mg} / \mathrm{kg}$ body weight) and routine infiltration anesthesia at the surgical site. The surgical site was shaved and disinfected. An incision was made in the scalp in the sagittal plane across the cranium, allowing reflection of a full-thickness flap in a posterior direction. A calvarial through-and-through osteotomy $7.0 \mathrm{~mm}$ in diameter was trephined into the dorsal portion of the parietal bone on each side of the midsagittal suture using a dental handpiece and a trephine bur (Messeinger, Duesseldorf, Germany) under constant irrigation with sterile saline and the trephined bone was removed from the surgical field. Straumann ${ }^{\circledast}$ BoneCeramic (particle size 500-1000 mm; Institut Straumann AG, Basel, Switzerland), a medical grade, particulate form of biphasic calcium phosphate comprising $60 \%$ hydroxyapatite and $40 \%$ b-tricalcium phosphate with a wide spongiosa structure, a wide interconnected pore system $(300-1500 \mu \mathrm{m})$ and a crystalline size of $10-60 \mathrm{~mm}$, was moistened with sterile saline for 5 min before being placed into the defect to fill in the defect area. At the end of the experiment, the calvarial bone was removed in oval shape of the temporal. Brain specimens in temporal regions were fixed in $10 \%$ buffered formalin for $1 \mathrm{~d}$, they were dehydrated in a graded ethanol series, cleaned in xylene and embeded in paraffin Then $4 \mu \mathrm{m}$ sections were cut and made into slides. These were processed for Hematoxylin-eosin.

Immunohistochemical Technique. Formaldehyde-fixed tissue was embedded in paraffin wax for further immunohistochemical examination. Sections were deparaffinized in absolute alcohol. Antigen retrieval process was performed twice in citrate buffer solution ( $\mathrm{pH}: 6.0$ ); the first for $7 \mathrm{~min}$, and later $5 \mathrm{~min}$ boiled in microwave owen at $700 \mathrm{~W}$. They were allowed to cool to room temperature for 30 $\mathrm{min}$ and washed twice in distilled water for $5 \mathrm{~min}$. Endogenous peroxidase activity was blocked in $0.1 \%$ hydrogen peroxide for $20 \mathrm{~min}$. Ultra V block (Cat. No:85-9043, Invitrogen, Carlsbad, CA, USA) was applied for 10 minutes prior to the application of primary antibodies (Abcam anti-GAFP antibody 1:100), (mouse monoclonal Bcl-2 Santa-Cruz) 1:100 and (Abcam VEGF anti- antibody), 1:100 overnight. Secondary antibody (Cat.No:85- 9043, Invitrogen, Carlsbad, CA, USA) was applied for $20 \mathrm{~min}$. Slides were then exposed to streptavidin-peroxidase for $20 \mathrm{~min}$. As a chromogen, diaminobenzidine (DAB Invitrogen, Carlsbad, CA, USA) was used. Control slides were prepared as mentioned above but omitting the primary anti bodies. After counterstaining with hematoxylin, washing in tap water for $8 \mathrm{~min}$ and in distilled water for $10 \mathrm{~min}$, the slides were mounted with entellan.

\section{RESULTS AND DISCUSSION}

Experimental group and control group were compared to histopathological sections. When the control group brain histopathological examination; pyramidal neurons was not observed any changes in the glial cells of the blood vessels. In Experimental group (Calvarial defects+Dexa+Synthetic graft); dilatation of blood vessels and hemorrhage, degenerative changes were observed in the blood brain barrier. Around blood vessels, in fibrillar structures we observed distortion and hyalinization some inflammatory cells. around blood vessels. Control animals displayed no reaction to VEGF in neuron, glial or endothelial cells, neither in grey nor white matter.

The initial mechanical impact can vary from superficial bruises to the head, to skull fracturing and direct damage to the brain. The primary damage to the brain often leads to secondary cascade of events such as breakdown of the duramater and the blood-brain barrier, edema, inflammation, change in ionic homeostasis, excitotoxicity, apoptosis and 




Fig.1.

a-Control group;Normal appearance of pyramidal neurons and glial cells in the cerebral cortex, H-E staning Bar $100 \mu \mathrm{m}$.

b- Calvarial defects+Dexa +Synthetic graft group, dilatation of blood vessels and hemorrhage, degenerative changes in the blood brain barrier, H-E staning Bar 50 $\mu \mathrm{m}$.

c- Control group; negative VEGF expression in capillary vessels, VEGF immunostaining Bar $100 \mu \mathrm{m}$.

d- Calvarial defects+Dexa+ Synthetic graft group, an increase in the expression of VEGF in neronal processes and endothelial cells of blood vessels VEGF immunostaining Bar $50 \mu \mathrm{m}$.

e- Control group; Regular distribution in astrocytes extension around the $\mathrm{v}$ e s s e l, w e a k GAFPexpressionGAFP immunostaining Bar $100 \mu \mathrm{m}$. f - C $\quad$ a 1 v defects+Dexa+Synthetic graft group, extension of astrocytes surrounding vessels, separation and degeneration GAFP positive expression, GAFP immunostaining Bar $50 \mu \mathrm{m}$. g- Control group; Bcl-2 negative expression in neurons and glial cells, Bcl-2 immunostaining Bar $50 \mu \mathrm{m}$. h-Control group; Calvarial defects+Dexa+Synthetic graft group, pyknotic nuclei in glial cells and glial apoptosis, $\mathrm{Bcl}-2$ positive reaction, $\mathrm{Bcl}-2$ immunostaining Bar $100 \mu \mathrm{m}$. 
pathological activation of various genes and biochemical processes (Lyeth et al., 1993; Laurer \& McIntosh, 1999; Tashlykov et al., 2007; Tweedie et al., 2007). The mTBI induced in the mice, did not produce external damage to the brain and its surrounding tissue (as examined by MRI), any skull fracture, no edema and no evident damage to the BBB (Pan et al., 2003; Zohar et al., 2003). However, although no peripheral damage was induced to the brain we demonstrated that the injury induce apoptosis to neurons in brain areas such as the hippocampus and the cortex. In this study, we demonstrated that glial apoptosis increased with head trauma in temporal regions. Some authors have described an upregulation of VEGF expression in several models of brain injury where VEGF mediates the disruption of the BBB and edema formation (Nag, 2002: Sköld et al., 2005). Vascular endothelial growth factor, induced by cerebral damage, was prominent in the area of infarction and appeared to be expressed both in pyramidal neuron, astroglia and in endothelial cells. In this study, VEGF disrupting the blood-brain barrier and inflammatory cytokine has been shown to be responsive.

Apoptosis has a major role in the mechanism of traumatic injury in the immature brain and is very severe in the brain of 7-day-old rats (Bayir et al., 2003). Apoptotic cell death is highest $24 \mathrm{~h}$ after trauma and continues for 7 more days (Bittigau et al., 1999). The amount of apoptosis necessary for physiological brain development is determined by the degree of myelinization and the water content of the brain (Smith et al.) It has been suggested that apoptosis of oligodendrocytes after traumatic CNS injury may be a result of either the direct trauma or a secondary event due to loss of trophic support from the degenerating axons (Beattie et al., 1998).

Also, determinating the age of injury by examining microscopic histopathological changes in inflammatory response with inflammatory stimuli as a result of the trauma has a great importance in forensic histopathology.

To estimate the age of an injury, remains one of the more difficult aspects within legal medicine. The use of inflammatory mediators or cells and matrix proteins in injured tissue will provide some clues to make an estimation (Frank R.W. van de Goot).

For implant development, made calvarial defects in experimental studies, minimal brain damage formation, astrocytes in neuronal damage and blood-brain barrier is thought to induce cellular apoptotic changes affected.

\section{CONCLUSIONS}

Calvarial defects caused by mild brain injury, to be induced by inflammatory cytokines, interrupting glial fibrillary degeneration by affecting the blood brain barrier is thought to promote apoptotic changes.

TAS, M.; GOK, E.; EKINCI, C.; DEVECI, E. \& DEVECI, S. Investigación de las alteraciones ocurridas en el tejido cerebral posterior a la creación de defectos en la calvaria de ratas. Int. J. Morphol., 34(1):29-33, 2016.

RESUMEN: Daños óseos, accidentes y traumas pueden alterar la vida normal de las personas y dañar los tejidos blandos. Este estudio tuvo como objetivo investigar los defectos de calota en ratas en función de la gravedad de la lesión cerebral que ocurre en una contusión de la región temporal. Las ratas fueron divididas aleatoriamente en dos grupos: al grupo 1 (control), se le realizó un modelo de defecto craneal de tamaño crítico sin tratamiento $(\mathrm{n}=10)$ y al grupo 2 , se le realizó un modelo de defecto craneal de tamaño crítico que fue tratado con dexametasona $(0,05 \mathrm{mg} / \mathrm{kg}$ vía i.m. $)$ + injerto sintético $(\mathrm{n}=10)(14 \mathrm{~d}$ con injerto sintético y el día 7 se le administró dexametasona). El modelo generó un defecto de $7 \mathrm{~mm}$ en el hueso parietal en cada animal, bajo anestesia general. Los defectos craneales produjeron dilatación de los vasos sanguíneos, hemorragias y deterioro en las estructuras gliales fibrilares. Además, el aumento de la expresión del factor de crecimiento vascular endotelial mostró una reacción con las positiva con la proteína ácida fibrilar de la glía el las extensiones de los astrocitos. Las células gliales apoptóticas se tiñeron positivas con Bcl-2. Los defectos de calota causan una lesión cerebral leve, inducidas por citoquinas inflamatorias, las que interrumpen la degeneración glial fibrilar al afectar la barrera hematoencefálica, induciendo cambios apoptóticos.

PALABRAS CLAVE: Defectos de calota; Rata; Cerebro; Inmunohistoquimica.

\section{REFERENCES}

Bayir, H.; Kochanek, P. M. \& Clark, R. S. Traumatic brain injury in infants and children: mechanisms of secondary damage and treatment in the intensive care unit. Crit. Care Clin., 19(3):52949, 2003.
Bittigau, P.; Sifringer, M.; Pohl, D.; Stadthaus, D.; Ishimaru, M.; Shimizu, H.; Ikeda, M.; Lang, D.; Speer, A.; Olney, J. W. \& Ikonomidou, C. Apoptotic neurodegeneration following trauma is markedly enhanced in the immature brain. Ann. Neurol., 45(6):724-35, 1999. 
Beattie, M. S.; Shuman, S. L. \& Bresnahan, J. C. Review: Apoptosis and spinal cord injury. Neurosci., 4(3):163-71, 1998.

Bignami, A. Glial Cells in the Central Nervous System. Amsterdam, Discussions in Neurosciences. Vol. 8.(1).Elsevier, 1991.pp.1-45.

Carmeliet, P. Blood vessels and nerves: common signals, pathways and diseases. Nat. Rev. Genet., 4(9):710-20, 2003.

Cernak, I. Animal models of head trauma. NeuroRx, 2(3):410-22, 2005.

Clark, R. S.; Chen, J.; Watkins, S. C.; Kochanek, P. M.; Chen, M.; Stetler, R. A.; Loeffert, J. E. \& Graham, S. H. Apoptosis-suppressor gene bcl-2 expression after traumatic brain injury in rats. $J$. Neurosci., 17(23):9172-82, 1997.

Dhillon, H. S.; Donaldson, D.; Dempsey, R. J. \& Prasad, M. R. Regional levels of free fatty acids and Evans blue extravasation after experimental brain injury. J. Neurotrauma, 11(4):405-15, 1994.

Esen, F.; Erdem, T.; Aktan, D.; Kalayci, R.; Cakar, N.; Kaya, M. \& Telci, L. Effects of magnesium administration on brain edema and blood-brain barrier breakdown after experimental traumatic brain injury in rats. J. Neurosurg. Anesthesiol., 15(2):119-25, 2003.

Frank R. W. van de Goot. The chronological dating of injury. In: Gy N. Rutty (ed). Essentials of Autopsy Practice Topical developments, trends and advances. Springer, London, 2008.

Fratzl, P.; Gupta, H. S.; Paschalis, E. P. \& Roschger, P. Structure and mechanical quality of the collagen-mineral nano-composite in bone. J. Mater. Chem., (14):2115-23, 2004.

Gentile, N. T. \& McIntosh, T. K. Antagonists of excitatory amino acids and endogenous opioid peptides in the treatment of experimental central nervous system injury. Ann. Emerg. Med., 22(6):1028-34, 1993.

Griesbach, G. S.; Sutton, R. L.; Hovda, D. A.; Ying, Z. \& Gomez-Pinilla, F. Controlled contusion injury alters molecular systems associated with cognitive performance. J. Neurosci. Res., 87(3):795-805, 2009.

Hobar, P. C.; Masson, J. A.; Wilson, R. \& Zerwekh, J. The importance of the dura in craniofacial surgery. Plast. Reconstr. Surg., 98(2):21725, 1996.

Hobar, P. C.; Schreiber, J. S.; McCarthy, J. G. \& Thomas, P. A. The role of the dura in cranial bone regeneration in the immature animal. Plast. Reconstr. Surg., 92(3):405-10, 1993.

Kerr, J. F.; Wyllie, A. H. \& Currie, A. R. Apoptosis: a basic biological phenomenon with wide-ranging implications in tissue kinetics. $\mathrm{Br}$. J. Cancer, 26(4):239-57, 1972.

Koshinaga, M.; Katayama, Y.; Fukushima, M.; Oshima, H.; Suma, T. \& Takahata, T. Rapid and widespread microglial activation induced by traumatic brain injury in rat brain slices. J. Neurotrauma, 17(3):185-92, 2000.

Laurer, H. L. \& McIntosh, T. K. Experimental models of brain trauma. Curr. Opin. Neurol., 12(6):715-21, 1999.
Lyeth, B. G.; Liu, S. \& Hamm, R. J. Combined scopolamine and morphine treatment of traumatic brain injury in the rat. Brain Res., 617(1):69-75, 1993.

Morales, D. M.; Marklund, N.; Lebold, D.; Thompson, H. J.; Pitkanen, A.; Maxwell, W. L.; Longhi, L.; Laurer, H.; Maegele, M.; Neugebauer, E.; Graham, D. I.; Stocchetti, N. \& McIntosh, T. K. Experimental models of traumatic brain injury: do we really need to build a better mousetrap? Neuroscience, 136(4):971-89, 2005.

Nag, S. The blood-brain barrier and cerebral angiogenesis: lessons from the cold-injury model. Trends Mol. Med., 8(1):38-44, 2002.

Pan, W.; Kastin, A. J.; Rigai, T.; McLay, R. \& Pick, C. G. Increased hippocampal uptake of tumor necrosis factor alpha and behavioral changes in mice. Exp. Brain Res., 149(2):195-9, 2003.

Rutty, G. N. Essentials of Autopsy Practice. New Advances, Trends and Developments. London, Springer, 2008.

Sköld, M. K.; von Gertten, C.; Sandberg-Nordqvist, A. C.; Mathiesen, T. \& Holmin, S. VEGF and VEGF receptor expression after experimental brain contusion in rat. J. Neurotrauma, 22(3):35367, 2005.

Smith, D. H.; Soares, H. D.; Pierce, J. S.; Perlman, K. G.; Saatman, K. E.; Meaney, D. F.; Dixon, C. E. \& McIntosh, T. K. A model of parasagittal controlled cortical impact in the mouse: cognitive and histopathologic effects. J. Neurotrauma, 12(2):169-78, 1995.

Tashlykov, V.; Katz, Y.; Gazit, V.; Zohar, O.; Schreiber, S. \& Pick, C. G. Apoptotic changes in the cortex and hippocampus following minimal brain trauma in mice. Brain Res., 1130(1):197-205, 2007.

Tweedie, D.; Milman, A.; Holloway, H. W.; Li, Y.; Harvey, B. K.; Shen, H.; Pistell, P. J.; Lahiri, D. K.; Hoffer, B. J.; Wang, Y.; Pick, C. G. \& Greig, N. H. Apoptotic and behavioral sequelae of mild brain trauma in mice. J. Neurosci. Res., 85(4):805-15, 2007.

Uhl, M. W.; Biagas, K. V.; Grundl, P. D.; Barmada, M. A.; Schiding, J. K.; Nemoto, E. M. \& Kochanek, P. M. Effects of neutropenia on edema, histology, and cerebral blood flow after traumatic brain injury in rats. J. Neurotrauma, 11(3):303-15, 1994.

Zohar, O.; Schreiber, S.; Getslev, V.; Schwartz, J. P.; Mullins, P. G. \& Pick, C. G. Closed-head minimal traumatic brain injury produces long-term cognitive deficits in mice. Neuroscience, 118(4):949-55, 2003.

Correspondence to:

Engin Deveci

Dicle University

Medical Faculty

Histology and Embryology Dept.

21280 Diyarbakir

TURKEY

Email: engindeveci64@gmail.com

Received: 04-03-2015

Accepted: $19-10-2015$ 